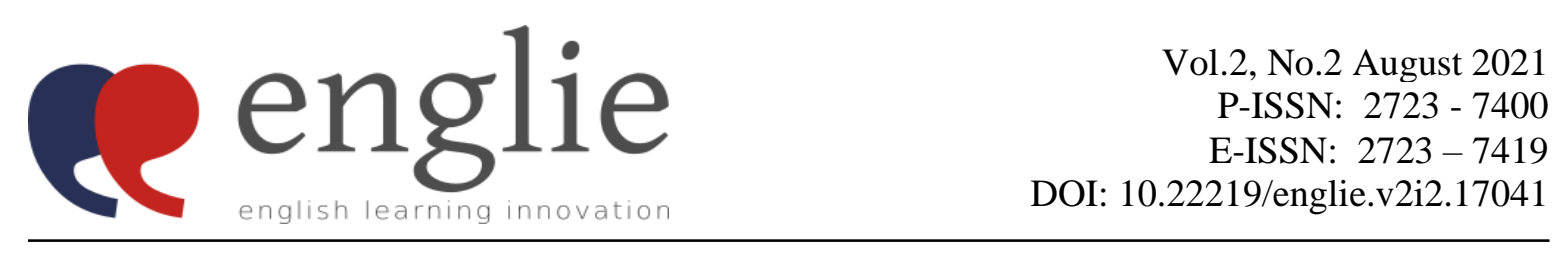

\title{
ESP Course Design for Indonesian Hotel Industry: Need Analysis
}

\author{
Yuyud Tri Guntoro
}

English Language Education Department, University of Muhammadiyah Malang, Indonesia

Corresponding author: yuyudtrig@webmail.umm.ac.id

\begin{abstract}
English for Specific Purpose (ESP) runs to equip learners' English language for their future needs in tertiary education. In the hotel industry, the laborers' English capabilities are crucial as their duties deal with foreign guests. However, hotel employees' English language inability was found in a small case. Thus, the ESP argues able to advance labor's English language skills. This research aims to identify staff's English needs in the front-desk department by identifying labors' lacks, wants, and necessities. Furthermore, this paper also seeks the expected ESP course. The data were collected toward three staff and a hotel manager by using the qualitative method. Additionally, interview and participant observation has established in Kapal Garden Hotel, Indonesia. The result are 1.) Speaking and listening are primary skills for a front desk job. It is in line with work necessities that front desk staff's duties are to communicate with foreign guests. The ESP course is expected to lead the students to pronounce vocabulary in hotels, respond to the conversation in the check-in and check-out situation, explain hotel facilities, direct the guest to a certain place, and understand the various foreign accents. 2.) The staff expects flexible teaching for ESP course design.
\end{abstract}

Keywords: ESP course design, hotel, need analysis

\section{INTRODUCTION}

English for Specific Purpose (ESP) has been adopted to provide learners English language in line with their future needs for a long time. Nowadays, ESP has been developed in tertiary education. The researcher has observed that ESP has become a compulsory course at the University of Muhammadiyah Malang. Also, ESP has been applied in the higher educations in Cambodia, Slovak, and Vietnam (Petraki \& Khat, 2020; Chmelíková \& Hurajová, 2019; Pham \& Ta, 2016). Explaining the reason some institutions applied ESP as their course, Lapele (2019) and Sumarsono et al., (2017) argue that it is to prepare graduates to succeed in the workforce. 
In hotel industry, the English language becomes a primary competence for employee's productivity due to the whole duties are serving the guest. In particular, the situation required to use English is when the foreign visitors stay in the hotel. Within the various department in the hotel industry, the researcher observed Front Desk Department as the department that most required English language use. It is drawn due to front desk staff's duties are answering guest's telephone, making a reservation, doing transactions, and explaining product knowledge. Afrianto \& Gulö (2019) moreover agree that front desk staff's English proficiency is important for dealing with the guest.

Although the ESP concept is adopted at the tertiary level, it is a little case of ESP has been applied in the company training. However, Panagiotopoulos et al., (2018) find that company training for the employee hones staffs' skills that affect their productivity. In line with that, this is believed that ESP provision for employees can provide English language skills. Therefore, Human Resource Capital is required to provide English courses to improve employees' self-competence. Moreover, the training is highly needed as English language barriers are still exist among hotel's front desk staffs (Datu, 2019).

Menggo et al., (2019) believe that need analysis is designed to help teacher in deciding material and identify learners' targets for achieving learning outcomes. Hence, conducting a need analysis for ESP teaching is important. Several studies stand on analyzing tourism program students' need toward the English language. Arsiyana \& Hernadi (2020) used interview and questionnaire toward lecturers, tourism experts, and students. That paper founds speaking and related material for tourism job are French students expectation in learning the English language. Puspitasari (2018) interviewed tourism experts yielding speaking, followed by listening, writing and reading as the students' need. Lertchalermtipakoon et al., (2021) interviewed tourism students revealed that listening and speaking skills are defined as as students lack in learning English.

The previous study of students' attitudes toward ESP has found that students support communicative approach teaching in ESP course (Process, 2010). Likewise, Rahmi et al., (2020) find students in ESP class are expected to be provided with fun activities, discipline without given pressure, and given professional material exposure. Arnó-Macià et al., (2020) also find a positive attitude of ESP as ESP allowed them to be more communicative and provided a great understanding of professional English. 
Reflecting the importance of ESP teaching in the company, this study seeks to identify student's English language needs, this presents paper identified the lacks, wants, and necessities. What makes this need analysis unique is the participant observation applicability. It is in accordance with Fine (2015) that argues observation allows the researcher to gain insight of human behavior and culture. That means the supporting document is drawn from the observatory instead of a hotel manager, and employee's viewpoint.

\section{METHOD}

The data was collected through qualitative design. The structural interview has established toward three staffs of the front desk department in Kapal Garden Hotel Malang and a hotel's manager who take responsibility as human capital. This paper also uses participant observation for four hours in length at the front desk service.

To define students' needs of English language, this paper identified employees' lacks, wants, and necessities. The question asked as follows:

1. Employees' difficulties in the English language production.

2. Work competencies that must be mastered for a front desk staff.

3. Expectation to learn English.

Secondly, to define the expected ESP course for employees training, the question asked is:

1. Meeting duration for ESP course

The thematic analysis was implemented to gain a clear explanation of expected ESP training, and need analysis. 


\section{FINDINGS AND DISCUSSION}

\section{Need Analysis of Front Desk Staff toward English Language}

\section{Lacks}

Table 1. The result of need analysis regarding the employees' difficulties to produce English language

\begin{tabular}{|c|c|c|c|c|}
\hline & Hotel Manager & Staff A & Staff B & Staff C \\
\hline $\begin{array}{l}\text { Employees' difficulties } \\
\text { to produce English } \\
\text { language, }\end{array}$ & $\begin{array}{l}\text { The staffs are } \\
\text { able to speak } \\
\text { English. In a } \\
\text { specific case, } \\
\text { when the staff } \\
\text { were asked } \\
\text { complex } \\
\text { questions, they } \\
\text { asked for help to } \\
\text { the other staff } \\
\text { who were more } \\
\text { capable in oral } \\
\text { English. }\end{array}$ & $\begin{array}{l}\text { It is hard for } \\
\text { me to speak } \\
\text { English. When } \\
\text { I was talking } \\
\text { with foreign } \\
\text { guests, I } \\
\text { answered the } \\
\text { questions with } \\
\text { limited } \\
\text { vocabulary. }\end{array}$ & $\begin{array}{l}\text { I have } \\
\text { difficulties } \\
\text { understanding } \\
\text { the British, } \\
\text { Indian, and } \\
\text { Arabic accents } \\
\text { and the } \\
\text { confusion lays } \\
\text { on selecting } \\
\text { contextual } \\
\text { vocabulary. I } \\
\text { was stuttered } \\
\text { when I was } \\
\text { communicating } \\
\text { with foreign } \\
\text { guests. }\end{array}$ & $\begin{array}{l}\text { When I was } \\
\text { speaking with } \\
\text { a foreigner, I } \\
\text { knew the } \\
\text { meaning. The } \\
\text { issue is I was } \\
\text { confused to } \\
\text { respond it. }\end{array}$ \\
\hline
\end{tabular}

The employees' lack has found through the hotel manager statement. He states the front desk staffs asked others for help when they were facing difficulties in English conversation. Moreover, the front desk staff added that they have difficulties to response the question in an English conversation. From these data, the conclusion can be drawn that the employees lack is speaking. Likewise, Datu (2019) also found the speaking English issues exist among hotel labor.

Regarding Staff B's statement that she faced difficulties to understand foreign English accent, it implies that listening skill is found to be their secondary needs. Likewise, Puspitasari 
(2018) identified tourism laborers are preferred to understand conversation from Chinese, Indians, and Japanese speakers.

\section{Necessities}

Table 2. The result of need analysis regarding the employees' necessities to produce English language

\begin{tabular}{lllll}
\hline & Hotel Manager & Staff A & Staff B & Staff C \\
\hline When do the Front Desk & They used & I used English & I used English & I used English \\
staffs use English & English when & when the & when the & when the \\
language? & the Front Desk & foreign guests & foreigners & foreign guests \\
& staff were & were asking & asked for & were staying \\
& making a room for help. & facilities and & here for check- \\
& transaction. In & location. & in. Commonly, \\
& a specific case, & & I used English \\
& English was & & when they \\
& used when the & & were asking for \\
foreigner & & & the price, room \\
& asked about & & capacity, and \\
& payment. & & facilities
\end{tabular}

The data above shows several situations that require staff to use English language. Based on the interview, the learners should be able to speak English in cashiering, checking-in and checking-out, explaining hotel facilities, and directing guests to a certain place. Similarly, Puspitasari (2018) finds tourism labor needs to understand the tourism map. Furthermore, front services in the hotel are night audit, financial management for room selling, and reservation (Liu \& Liu, 2021)

Notwithstanding, the observation result concludes front desk staff uses English for an administrative manner to input guests' databases. Meanwhile, front desk staff are required to understand terminology meaning in the computer system. This is justified with documented computer system below: 


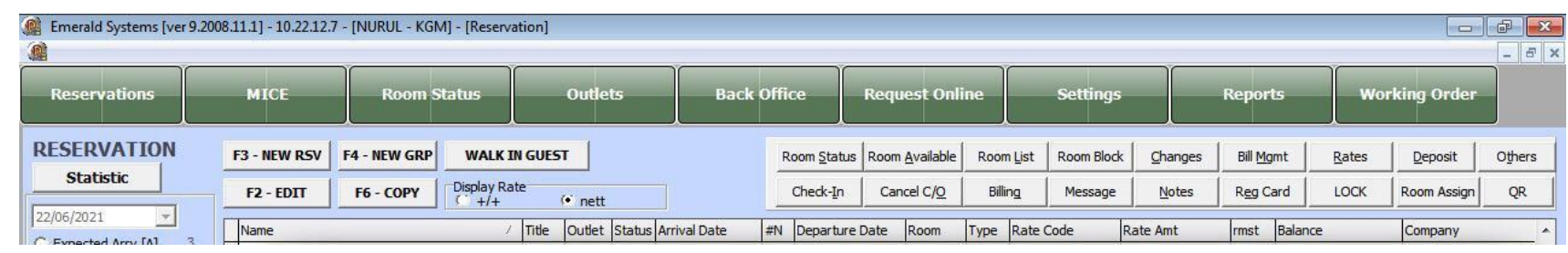

Figure 1. Computer system in front desk department that the staff used.

Whereas, teaching the meaning of English terminology of computer system is not important because the staff does not have any issues in doing administrative work. Based on the participatory observation, the staffs' administrative duties was expeditious.

\section{Wants}

Table 3. The result of need analysis regarding the employees' expectation to learn English language

\begin{tabular}{|c|c|c|c|c|}
\hline & Hotel Manager & Staff A & Staff B & Staff C \\
\hline $\begin{array}{l}\text { What do they expect } \\
\text { from learning } \\
\text { English? }\end{array}$ & $\begin{array}{l}\text { I hope that front } \\
\text { desk staffs can } \\
\text { improve their } \\
\text { pronunciation. } \\
\text { Not to make them } \\
\text { as native, but it is } \\
\text { for better } \\
\text { communication } \\
\text { thus improving } \\
\text { hotel's image }\end{array}$ & $\begin{array}{l}\text { I want to enroll } \\
\text { the course, } \\
\text { because I feel } \\
\text { that my } \\
\text { speaking needs } \\
\text { to be } \\
\text { improved. }\end{array}$ & $\begin{array}{l}\text { As I said that } \\
\text { my English is } \\
\text { on the passive } \\
\text { level. Hence, if } \\
\text { I offered a } \\
\text { course, I want } \\
\text { it. }\end{array}$ & $\begin{array}{l}\text { For front office } \\
\text { staffs, English } \\
\text { skills are } \\
\text { important. }\end{array}$ \\
\hline
\end{tabular}

The data above show that the hotel manager's expectation toward the front desk staff is to master pronunciation skills. As a part of communication, staff A and B agree that they want to improve their speaking. However, staff $\mathrm{C}$ explicitly agree due to the reason why English is important. In conclusion, front desk staffs want to improve their English speaking either for personal reason and for professional reason. In addition, a hotel manager wants the front desk staff to improve pronunciation skills. Moreover, the observation result shows that the staff already use vocabulary in English. The vocabulary used in particular 'Check-in' 'Check-out 
'Breakfast' 'Triple Deluxe' 'Standard' 'Superior' 'Standard Twin' 'Upgrade' 'Standard Double' 'Bed'. Thus, hotel-vocabulary-pronunciation should be taught in ESP training. Agree with this, Arnó-Macià et al., (2020) argue communication engagement becomes the student's expectation of ESP course.

\section{Expected ESP Training}

Table 4. The data gained from interview

\begin{tabular}{lcccc}
\hline & Hotel Manager & Staff A & Staff B & Staff C \\
\hline Meeting duration of ESP & 1 time & 1 until 2 times & 1 until 2 & Should have \\
training in a week & & depends on & times & training in a \\
& Hotel & & week \\
& occupancy & & \\
& & &
\end{tabular}

\begin{tabular}{|c|c|c|c|c|c|c|c|c|c|c|c|}
\hline 6 & Sun & Mon & Tue & Wed & Thu & Fri & Sat & Sun & Mon & Tue & Wed \\
\hline 7 & 11 & 12 & 13 & 14 & 15 & 16 & 17 & 18 & 19 & 20 & 21 \\
\hline \multicolumn{12}{|l|}{8} \\
\hline 9 & A & A & & & & & MD1 & M & M & M & M \\
\hline 10 & & M & M & M & M & M & M & . & . & M8 & . \\
\hline 11 & & M8 & A & A & A & A & . & & & 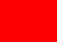 & M8 \\
\hline 12. & M & & & & & 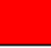 & A & A & A & A & A \\
\hline 13 & . & & & & & $\mathrm{N}$ & $\mathrm{N}$ & $\mathrm{N}$ & $\mathrm{N}$ & $\mathrm{N}$ & . \\
\hline 14 & $\mathrm{~N}$ & $\mathrm{~N}$ & $\mathrm{~N}$ & $\mathrm{~N}$ & $\mathrm{~N}$ & & & & & & $\mathrm{~N}$ \\
\hline \multicolumn{12}{|l|}{15} \\
\hline 16 & & & & & & & & & & & \\
\hline 17 & \multicolumn{11}{|c|}{ berubah sevaktu-waktu } \\
\hline 18 & M: & $07.00-15.00$ & & & & & & & & & \\
\hline 19 & M1: & $09.00-17.00$ & & & & & & & & & \\
\hline 20 & M8 : & $08.00-16.00$ & & SALES & & & & & & & \\
\hline 21 & MD1: & $12.00-20.00$ & & & & & & & & & \\
\hline 22 & A: & $15.00-23.00$ & & & & & & & & & \\
\hline 23 & $\mathrm{~N}:$ & $23.00-07.00$ & & & & & & & & & \\
\hline
\end{tabular}

Figure 2. The data above is front desk staff's schedule. The staff's name was deleted in the left side.

In accordance with the meeting duration, the subjects expect the course to be held once up to twice a week. Meanwhile, the course further should be more flexible. This is also based on the participatory result that shows the staff work for eight hours long in the unstable work time (MD1 to M, M8 to A). Therefore, the staff has limited time to study. That is in-line with 
Rahmi et al., (2020) who believe ESP students are expected to be taught with less pressure and fun activities.

\section{CONCLUSION}

Regarding the ESP-believes that can provide English skills as the learners has expected, ESP course used to emerge by human capital in the hotel industry. ESP preferred to train front desk staff as they deal with the guest directly. Moreover, the front desk staff expects to have weekly training to improve their English skills. Furthermore, ESP training flexibility is important, as hotel workers work at dynamic hours. Additionally, ESP is expected to engage English speaking and listening skills. Explaining the reason for this, the difficulties to respond conversation between staff and foreign guest, yet the difficulties to understand variety accent was found. In addition, the material should be taught are pronouncing hotel's vocabulary, responding the conversation in check-in and check-out situation, explaining hotel facilities, directing guest to the certain place, and listening various foreign accent.

\section{ACKNOWLEDGMENT}

The completion of this research might not be achieved without the Curriculum Studies course at the English Education Department, University of Muhammadiyah Malang. My deep thankfulness for the Curriculum Studies' lecturer, Mr. Teguh Hadi Saputro, M.A., Kapal Garden Hotel Malang Manager. Secondly, thanks to Kapal Garden Hotel's front desk team, especially Rizkia regarding the time for the interview. Lastly, with support by Pindy Widya Puji Lestari, Siska Anggi Rifani, Junaefi, and Rizkia Nabila the data were completed.

\section{REFERENCES}

Afrianto, A., \& Gulö, I. (2019). Revisiting English Competence at Hotel. TEKNOSASTIK. https://doi.org/10.33365/ts.v17i1.248

Arnó-Macià, E., Aguilar-Pérez, M., \& Tatzl, D. (2020). Engineering Students' Perceptions of The Role of ESP Courses in Internationalized Universities. English for Specific Purposes. https://doi.org/10.1016/j.esp.2019.12.001

Arsiyana, M., \& Hernadi, N. (2020). A Comprehensive Needs Analysis of French Course for 
Tourism and Hospitality Program. JURNAL ARBITRER. https://doi.org/10.25077/ar.7.1.51-61.2020

Chmelíková, G., \& Hurajová, L. (2019). ESP Teachers in the World of Globalisation and Higher Education Internationalisation. Journal of Teaching English for Specific and Academic Purposes. https://doi.org/10.22190/jtesap1904443c

Datu, Y. A. (2019). English Proficiency of Hotel Front-Liners: What and Why? Jurnal Bisnis Terapan. https://doi.org/10.24123/jbt.v3i02.2506

Fine, G. A. (2015). Participant Observation. In International Encyclopedia of the Social \& Behavioral Sciences: Second Edition. https://doi.org/10.1016/B978-0-08-0970868.44041-9

Lapele, F. (2019). Need Analysis on the Material Development of Teaching ESP Speaking. ETERNAL (English, Teaching, Learning, and Research Journal). https://doi.org/10.24252/eternal.v52.2019.a13

Lertchalermtipakoon, P., Wongsubun, U., \& Kawinkoonlasate, P. (2021). Need Analysis: English Language Use by Students in the Tourism and Hospitality and Industry. English Language Teaching. https://doi.org/10.5539/elt.v14n3p59

Liu, X., \& Liu, X. (2021). On the structure and modules of hotel management information system of reception. ACM International Conference Proceeding Series. https://doi.org/10.1145/3456887.3457113

Menggo, S., Suastra, I. M., Budiarsa, M., \& Padmadewi, N. N. (2019). Needs analysis of academic-English speaking material in promoting 21 st century skills. International Journal of Instruction. https://doi.org/10.29333/iji.2019.12247a

Panagiotopoulos, G., Giannouli, D., \& Karanikola, Z. (2018). the Contribution of in-Company Training To Skills Improvement and Human Resources Development. International Journal of Education, Learning and Development.

Petraki, E., \& Khat, K. (2020). Challenges and constraints in the design of an ESP course in Cambodia: implications for higher education institutions. Asia Pacific Journal of Education. https://doi.org/10.1080/02188791.2020.1798738

Pham, H. A., \& Ta, B. T. (2016). Developing a Theoretical Framework for ESP Teacher 
Training in Vietnam. Asian ESP Journal.

Process, B. (2010). Attitudes Toward Esp Among University Students. Fluminensia: Journal for Philological Research, 22(2), 145-161.

Puspitasari, I. (2018). Developing English for Tourism Materials trough Stakeholders: Needs Analysis. English Review: Journal of English Education. https://doi.org/10.25134/erjee.v7i1.1534

Rahmi, R., Abduh, A., \& Sofyan, M. (2020). Student Perception of ESP Business English Teaching Implementation in Makassar National Informatics Polytechnic. Jurnal Ad'ministrare. https://doi.org/10.26858/ja.v6i2.12514

Sumarsono, P., Masyhud, Wardhani, A., \& Farah, R. R. (2017). The Development of Authentic English Language Teaching (ELT) textbook of vocational school. International Journal of English Research, 3(6), 29-31. https://repository.usd.ac.id/9805/2/101214037_full.pdf 